\section{Identification of Putative Kunitz-Type Proteinase Inhibitor as an Allergenic Protein in Potato}

\author{
Carolino $\mathrm{F}^{1}$, Ferreira $\mathrm{A}^{1}$, Martínez $\mathrm{J}^{2}$, Cernadas JR ${ }^{1}$ \\ ${ }^{I}$ Serviço de Imunoalergologia, Centro Hospitalar São João, \\ E.P.E., Porto, Portugal \\ ${ }^{2}$ Departamento de Inmunología, Microbiología y Parasitología, \\ Facultad de Farmacia, Universidad del País Vasco, Vitoria- \\ Gasteiz, Spain
}

J Investig Allergol Clin Immunol 2016; Vol. 26(4): 263-264 doi: $10.18176 /$ jiaci.0063

Key words: Solanum tuberosum. Allergens. Food Hypersensitivity. Putative Kunitz-type proteinase inhibitor.

Palabras clave: Solanum tuberosum. Alérgenos. Alergia Alimentaria. Inhibidores de tripsina del tipo Kunitz.

Cooked potato (Solanum tuberosum) is one of the first solid foods in a child's diet and is considered to be safe, although a European questionnaire-based study at 17 clinics from 15 cities found potato to be the 25 th most prevalent cause of self-reported allergic symptoms [1]. Potato is also used to make emollients and cleansing masks.

Allergic reactions to raw and cooked potato have multiple clinical presentations. In sensitized individuals, handling raw potato can induce immediate IgE-mediated manifestations, namely, respiratory involvement and contact dermatitis. Ingestion of cooked potato can trigger both immediate and late reactions, such as chronic eczema flares; there are reports of anaphylaxis following exposure to this tuber $[2,3]$.

A 2-year-old white boy was referred to our allergy department with a history of lip edema and surrounding erythema a few minutes after ingestion of his first soup (made of potato, carrot, and pumpkin) when he was 4 months old. No respiratory, gastrointestinal, or cardiovascular signs or symptoms were reported. After the initial episode, the same clinical picture was triggered every time the child ate the same soup, with complete and spontaneous resolution of symptoms between episodes. The child's mother sequentially withdrew each ingredient from the soup, eventually realizing that symptoms were elicited by the ingestion of potato. After a similar reaction when hen egg was introduced, a strict potato and egg avoidance diet was started, and the symptoms resolved. The remaining foods were introduced without further reactions. The child had previously undergone orchidopexy.

The physical examination was normal, and skin prick tests to aeroallergens and latex extracts (Leti) were negative. Given the relatively long duration of the avoidance diet, we first performed additional prick-to-prick tests with raw and cooked potato. The results were positive to raw potato (at 2 and 4 years of age). The ImmunoCAP FEIA system (Phadia) revealed an increase in specific $\operatorname{IgE}\left(\mathrm{kU}_{\mathrm{A}} / \mathrm{L}\right)$ to $S$ tuberosum $(23.60,>100$, and 63.90 at 2, 3, and 4 years of age, respectively); specific IgE to latex was below $0.35 \mathrm{kU}_{\mathrm{A}} / \mathrm{L}$. The ImmunoCAP ISAC Microarray Panel summary of positive IgE results (ISU) was as follows: Gal d 1, 2.7; Gal d 2, 1.4; Act d 1, 1.0.

After the initial in vivo skin tests and in vitro tests, an oral food challenge was proposed, although it was not performed before the age of 5 years owing to parental refusal. The oral challenge with cooked potato was negative, thus enabling reintroduction of cooked potato in the child's regular diet.

With a serum sample from our patient and raw potato extract, 2-dimensional immunoblotting and MALDI-TOF/TOF mass spectrometry analysis made it possible to identify and characterize an IgE-reactive protein that exhibited sequence homology with putative Kunitz-type proteinase inhibitor of $S$ tuberosum (molecular weight of $20.491 \mathrm{kDa}$ and isoelectric point of 5.17) (Figure) [4].

Only 4 potato allergens have been characterized, namely, patatin (Sol t 1) and 3 water-soluble glycoproteins that are

\begin{tabular}{|llllll|}
\hline 1 & MKCLFLLCLC & LVPIVVFSST & FTSQNPINLP & SDATPVLDVT & GKELDSHLSY \\
51 & RIISTFWGAL & GGDVYLGKSP & NSDAPCANGI & FRYNSDVGPS & GTPVRFIGSS \\
101 & SHFGQGIFEN & ELLNIQFAIS & TSKLCVSYTI & WKVGDYDASL & GTMLLETGGT \\
151 & IGQADSSWFK & IVKSSQLGYN & LLYCPVTSTM & ICPLFL & \\
\hline
\end{tabular}

Figure. Protein sequence (186 amino acids).

resistant to acids and proteases (Sol t 2, Sol t 3, and Sol t 4) $[5,6]$.

Patatin (Sol t 1), a storage protein with phospholipase A2 activity and a molecular weight of $43 \mathrm{kDa}$, is a major potato allergen and accounts for $40 \%$ of total soluble proteins [5]. The minor allergen of latex Hev b 7 has a sequence homology of $39 \%$ to $42 \%$ with patatin and seems to be an important natural rubber latex allergen for adults, but not for children [7]; still, cross-reactivity between these allergens in latex-allergic patients does not seem to be clinically relevant [5].

Sol t 2 (cathepsin D), Sol 3 (cysteine), and Sol t 4 (aspartic protease inhibitor of potato tuber) are 16 to $20-\mathrm{kDa}$ proteins with similar sequences that belong to the Kunitz-type soybean trypsin inhibitor family [6]. Specific IgE-binding to these proteins has been reported in $43 \%-67 \%$ of atopic children suspected of having allergy to potato, and it seems that there is cross-reactivity between Sol t 2, Sol t 3, and Sol t 4, but not with Sol t 1 [6].

The potato protein-binding IgE from our patient's serum is structurally different from the proteins belonging to the soybean trypsin inhibitor family, which were described by Seppälä et al [6] as allergens. Therefore, we believe ours is 
the first description of this protein as allergenic. Our patient was sensitized to the potato protein described and to the kiwi allergen Act d 1, with no sensitization to other plant food allergens or to airborne allergens, namely, tree, weed, or grass pollens, although he did have symptoms suggestive of allergic rhinitis.

In the case we report, the child presented with reproducible allergic symptoms related to the ingestion of cooked potato, even though the result of prick-to-prick testing was negative. This finding highlights the importance of performing a controlled food challenge in order to achieve a definitive diagnosis of food allergy. The IgE-binding protein identified was a putative Kunitz-type proteinase inhibitor, which, to our knowledge, has not been previously described as allergenic.

As for prognosis, tolerance to cooked potato is achieved in up to $80 \%$ of children by the age of 4 years (16-102 months), and allergy to cooked potato emerges as a risk factor for the development of pollen allergy [8]. In patients with potato allergy, an avoidance diet is recommended, and a food challenge can be attempted after a potato-free period of about 6 months [8].

\section{Funding}

The authors declare that no funding was received for the present study.

\section{Conflicts of Interest}

The authors declare that they have no conflicts of interest.

\section{Previous Presentation}

The data we report here were presented in abstract and poster form at the European Academy of Allergy and Clinical Immunology Congress, Copenhagen, Denmark, June 2014.

\section{References}

1. Eriksson NE, Möller C, Werner S, Magnusson J, Bengtsson U, Zolubas M. Self-reported food hypersensitivity in Sweden, Denmark, Estonia, Lithuania, and Russia. J Investig Allergol Clin Immunol. 2004;14(1):70-9.

2. Beausoleil JL, Spergel JM, Pawlowski NA. Anaphylaxis to raw potato. Ann Allergy Asthma Immunol. 2001;86:68-70.

3. De Swert LF, Cadot P, Ceuppens JL. Allergy to cooked white potatoes in infants and young children: a cause of severe, chronic allergic disease. J Allergy Clin Immunol. 2002;110(3):524-35.

4. Heibges A, Glaczinski H, Ballvora A, Salamini F, Gebhardt C. Structural diversity and organization of three gene families for Kunitz-type enzyme inhibitors from potato tubers (Solanum tuberosum L.). Mol Genet Genomics. 2003;269(4):526-34.

5. Seppälä U, Alenius H, Turjanmaa K, Reunala T, Palosuo T, Kalkkinen N. Identification of patatin as a novel allergen for children with positive skin prick test responses to raw potato. J Allergy Clin Immunol. 1999;103:165-71.

6. Seppälä U, Majamaa H, Turjanmaa K, Helin J, Reunala T, Kalkkinen $\mathrm{N}$, Palosuo T. Identification of four novel potato
(Solanum tuberosum) allergens belonging to the family of soybean trypsin inhibitors. Allergy. 2001;56(7):619-26.

7. Sowka S, Hafner C, Radauer C, Focke M, Brehler R, Astwood JD, Arif SA, Kanani A, Sussman GL, Scheiner O, Beezhold DH, Breiteneder $\mathrm{H}$. Molecular and immunologic characterization of new isoforms of the Hevea brasiliensis latex allergen Hev b 7: evidence of no cross-reactivity between Hev b 7 isoforms and potato patatin and proteins from avocado and banana. J Allergy Clin Immunol. 1999;104(6):1302-10.

8. De Swert LF, Cadot P, Ceuppens JL. Diagnosis and natural course of allergy to cooked potatoes in children. Allergy. 2007;62(7):750-57.

Manuscript received August 13, 2015; accepted for publication March 14, 2016.

Fabrícia Carolino

Serviço de Imunoalergologia, Centro Hospitalar São João, E.P.E.

Alameda Prof. Hernâni Monteiro, 4200-319 Porto, Portugal E-mail: fabricia.carolino@gmail.com 


\section{Exudative Erythema Multiforme Due to Cyclobenzaprine}

Gómez Torrijos E ${ }^{1}$, García Arpa $\mathrm{M}^{2}$, García Rodríguez $\mathrm{C}^{1}$, Mendez Díaz $\mathrm{Y}^{1}$, Borja Segade ${ }^{1}$, Galindo Bonilla $\mathrm{PA}^{1}$, Feo Brito JF${ }^{1}$, García Rodríguez $\mathrm{R}^{1}$

${ }^{1}$ Allergy Department, Hospital General Universitario de Ciudad Real, Ciudad Real, Spain

${ }^{2}$ Dermatology Department, Hospital General Universitario de Ciudad Real, Ciudad Real, Spain

J Investig Allergol Clin Immunol 2016; Vol. 26(4): 265-266 doi: 10.18176/jiaci.0064

Key words: Cyclobenzaprine. Exudative erythema multiforme. Muscle relaxants. Patch tests. Tricyclic antidepressants.

Palabras clave: Ciclobenzaprina. Eritema exudativo multiforme. Relajantes musculares. Test del parche. Antidepresivos tricíclicos.

Cyclobenzaprine belongs to a heterogeneous class of medications known as muscle relaxants. More specifically, it is classified as an antispasmodic [1]. It is structurally similar to the tricyclic antidepressants (eg, amitriptyline) [2] and has similar associated adverse effects, including dizziness and drowsiness. Sedation is the most common adverse effect at the usual dosage of $10 \mathrm{mg} / 8 \mathrm{~h}$ [3]. The use of skeletal muscle relaxants among older adults is associated with sedation and confusion, which may lead to an increased risk of falls and injuries [4].

A 56-year-old atopic woman with no history of herpes simplex virus infection was treated with dexketoprofen ( $25 \mathrm{mg} / 12$ hours) and cyclobenzaprine (Yurelax, $10 \mathrm{mg} / 8$ hours) for 10 days owing to movement-limiting muscle pain in her neck and back. A day after discontinuation of this treatment, she self-medicated with topical fluocortolone $0.2 \%$ for 5 days to treat dyshidrosis. She also took a single dose of ibuprofen $600 \mathrm{mg}$. Five days after the last dose of dexketoprofen and cyclobenzaprine, 3 days after the only dose of ibuprofen, and the day following discontinuation of fluocortolone, she presented with erythematous-edematous plaques, which mostly took the form of target lesions on the forearms and wrists, together with lesions affecting the oral mucosa that produced itching, burning sensation, and diffuse discomfort in the mouth and pharynx when eating and swallowing food. The skin lesions subsided within a week with topical dermal clobetasol $0.05 \%$ (Clovate, 2 applications/day).

The results of patch testing-cyclobenzaprine, carbamazepine, oxcarbamazepine, phenytoin, amitriptyline, and phenobarbital at $2 \%$ and $20 \%$ in water and petrolatumwere negative at both 48 hours and 96 hours.

A biopsy sample of the lesions revealed dermatitis with slight spongiosis and the presence of microvesicles. A mild inflammatory infiltrate was also detected on the perivascular surface, with focal damage of the interface and vacuolar degeneration. Focal parakeratosis and mild exocytosis were present. No keratinocytic necrosis was observed. Periodic acid-Schiff staining for fungi was negative. Findings were consistent with exudative erythema multiforme (EEM).

Ibuprofen (1200 mg) and dexketoprofen (75 mg for 4 days) were well tolerated in controlled oral challenges tests.

The oral challenge tests with cyclobenzaprine (Yurelax) revealed no immediate symptoms. The patient was advised to take $10 \mathrm{mg}$ /day for 4 days at home, and 24 hours after the last dose she presented macular target lesions on her forearms and lesions on the oral mucosa that were very similar to those she had previously experienced (Figure). The result of an open challenge with Ultralan cream was negative.

Cyclobenzaprine is a tricyclic antidepressant with possible adverse anticholinergic effects, the most feared of which are cardiac and central nervous system disorders [5]. The drug is highly metabolized in the liver, has a long elimination halflife (1-3 days), and can produce toxic effects [6]. Few cases of allergy to these drugs have been reported in the literature and, as far as we know, only 1 case of delayed allergy (contact dermatitis to cyclobenzaprine) has been published [7]. The skin and oropharyngeal lesions observed in the case we report were compatible with EEM, and the diagnosis was confirmed with a skin biopsy. As the patient did not report a history of herpes simplex labialis but had received previous treatment with multiple drugs, we performed an allergy study with the drugs involved using patch tests, a use test with the topical medication, and oral challenge tests with the alleged culprit drugs. All test results were negative except for the challenge test with cyclobenzaprine, which induced similar lesions on the skin and oral mucosa. Therefore, we confirmed that the skin symptoms were drug-induced, with cyclobenzaprine as the causative drug. Given the chemical similarity to other anticonvulsant drugs, and especially to tricyclic antidepressants, we performed patch tests as reported elsewhere [8]. The results of these tests were negative, even for the culprit drug, although we did not conclude the cross-reactivity study with challenge tests for ethical reasons (ie, the reaction could be potentially severe). Only 1 case of cross-reactivity between tricyclic antidepressants and anticonvulsants has been reported [9].

As in drug rash with eosinophilia and systemic symptoms, EEM occurs more rapidly in previously sensitized patients [10].

We report the first case of EEM triggered by cyclobenzaprine that was confirmed with biopsy and a positive challenge test result.

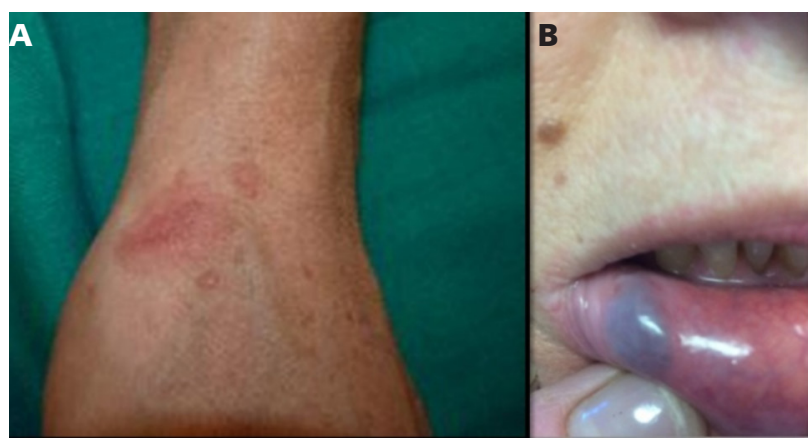

Figure. A, Skin lesion. B, Lesion affecting the oral mucosa. 


\section{Funding}

The authors declare that no funding was received for the present study.

\section{Conflicts of Interest}

The authors declare that they have no conflicts of interest.

\section{References}

1. See S, Ginzburg R. Skeletal muscle relaxants. Pharmacotherapy. 2008;28(2):207-13.

2. Kraus MB, Wie CS, Gorlin AW, Wisenbaugh ES, Rosenfeld DM. Painful Ejaculation with Cyclobenzaprine: A Case Report and Literature Review. Sex Med. 2015;3(4):343-5.

3. Borenstein DG, Korn S. Efficacy of a low-dose regimen of cyclobenzaprine hydrochloride in acute skeletal muscle spasm: results of two placebo-controlled trials. Clin Ther. 2003;25:1056-73.

4. Spence MM, Shin PJ, Lee EA, Gibbs NE. Risk of injury associated with skeletal muscle relaxant use in older adults. Ann Pharmacother. 2013;47:993-8.

5. Kerr GW, McGuffie A, Wilkie S. Tricyclic antidepressant overdose: a review. Emerg Med. Emerg Med J. 2001;18(4):23641.

6. Brioschi TM, Schramm SG, Kano EK, Koono EE, Ching TH, Serra $\mathrm{CH}$, Porta V. Pharmacokinetics and bioequivalence evaluation of cyclobenzaprine tablets. Biomed Res Int. 2013;2013;281392.

7. Turrentine JE, Marrazzo G, Cruz PD Jr. Novel use of patch testing in the first report of allergic contact dermatitis to cyclobenzaprine. Dermatitis. 2015;26:60-1.

8. Brajon D, Trecho P Waton J, Cuny JF, Schmutz JL, Barbaud A. Suspicion of a New Cross-reaction Between Carbamazepine and Olanzapine. J Investig Allergol Clin Immunol. 2014;24:5671.

9. Ljunggren B, Bojs G. A case of photosensitivity and contact allergy to systemic tricyclic drugs, with unusual features. Contact Dermatitis. 1991;24:259-65.

10. EM Macías, Muñoz-Bellido FJ, Velasco A, Moreno E, Dávila I. DRESS Syndrome Involving 2 Unrelated Substances: Imipenem and Iodinated Contrast Media. Investig Allergol Clin Immunol. 2013;23(1):50-73

- Manuscript received December 13, 2015; accepted for publication March 14, 2016.

Elisa Gómez Torrijos Allergy Section Hospital general de Ciudad Real c/ Obispo R Torija, s/n 13005 Ciudad Real, Spain E-mail: egomezt.cr@gmail.com
Anaphylaxis to 2 NSAIDs in a Patient Who Tolerated ASA

Bogas $\mathrm{G}^{1}$, Pérez-Sánchez $\mathrm{N}^{1}$, Andreu $\mathrm{I}^{2}$, Doña $\mathrm{I}^{1}$, Perkins $\mathrm{JR}^{3}$, Blanca $\mathrm{M}^{1}$, Canto $\mathrm{G}^{4}$, Cornejo-García JA ${ }^{1,3}$, Blanca-López $\mathrm{N}^{4}$ ${ }^{1}$ Allergy Unit, Malaga Regional University Hospital-IBIMA, Malaga, Spain

${ }^{2}$ Chemical Technology Institute, UPV-CSIC, Polytechnic University of Valencia, Valencia, Spain

${ }^{3}$ Research Laboratory, IBIMA, Regional University Hospital of Malaga, UMA, Malaga, Spain

${ }^{4}$ Allergy Service, Hospital Infanta Leonor, Madrid, Spain

J Investig Allergol Clin Immunol 2016; Vol. 26(4): 266-268 doi: 10.18176/jiaci.0066

Key words: NSAID hypersensitivity. Cross-intolerance. Selective reactions. Anaphylaxis. ASA tolerance.

Palabras clave: Hipersensibilidad a AINE. Intolerancia cruzada. Reacciones selectivas. Anafilaxia. Tolerancia a AAS.

Nonsteroidal anti-inflammatory drugs (NSAIDs) are the most frequent cause of drug hypersensitivity [1]. NSAIDinduced reactions can be classified into 5 categories: (1) NSAID-exacerbated respiratory disease (NERD); (2) NSAIDexacerbated cutaneous disease (NECD); (3) NSAID-induced urticaria and/or angioedema (NIUA); (4) single NSAIDinduced urticaria/angioedema/anaphylaxis (SNIUAA); and (5) single NSAID-induced delayed hypersensitivity reactions (SNIDR) [2]. Patients in the first 3 categories react to NSAIDs from various chemical groups in a nonallergic type of drug hypersensitivity known as cross-intolerance. The mechanism involved in these reactions is thought to be related to an imbalance in the arachidonic acid metabolic pathway leading to increased release of cysteinyl leukotrienes [2,3]. Patients with SNIUAA and SNIDR respond to only 1 NSAID and are known as selective reactors, an allergic type of drug hypersensitivity based on specific immunological mechanisms [2,3]. Although significant progress has been made in phenotyping these reactions during recent years, it is now accepted that some cases do not fit properly into the classification proposed by the ENDA group [4,5], and further subgroups may be needed for a better definition of phenotypes [6].

We present the case of a 56-year-old white man with allergic rhinitis and sensitization to common inhalant allergens who had experienced an anaphylactic reaction to ibuprofen 5 years previously. The original diagnostic workup was performed following guidelines [2,7]. Incremental doses of acetylsalicylic acid (ASA) were given in a single-blind, placebo-controlled manner until the therapeutic dose was tolerated. Two days later, the patient tolerated $500 \mathrm{mg}$ of ASA every 8 hours for 2 days. A week later, controlled administration with ibuprofen was started as described elsewhere [7]. On the first day, placebo was administered at different time intervals, with no reaction. On the second day, the patient was given $5 \mathrm{mg}$ of ibuprofen 
followed 90 minutes later by a second dose of $50 \mathrm{mg}$. After 20 minutes, he developed pruritus on the palms and soles and facial erythema with hoarseness, nasal obstruction, and itching (cumulative dose of $55 \mathrm{mg}$ ). No cardiovascular symptoms were reported. He was classified as a selective reactor to ibuprofen and was recommended to avoid arylpropionic acid derivatives including ibuprofen, naproxen, and dexketoprofen.

Since then, he has been taking oral diclofenac on a regular basis to treat chronic back pain. On several occasions, he has also applied ointment to the knees and eye drops, both of which contain diclofenac. He has also taken paracetamol $(1 \mathrm{~g})$ on several occasions and low doses of ASA (100 mg) to prevent thrombosis.

The patient attended the emergency unit because he experienced a reaction 10 minutes after taking $75 \mathrm{mg}$ of diclofenac. The reaction comprised systemic pruritus that started on the palms and soles, followed by erythema on the face and trunk and breathing difficulty with hypotension $(100 / 60 \mathrm{mmHg})$ and tachycardia $(120 \mathrm{bpm})$. He was given corticosteroids and antihistamines plus fluids and adrenaline. His symptoms subsided several hours after treatment. Five days previously, he had taken $50 \mathrm{mg}$ of diclofenac with symptoms that were similar but of lower intensity. The symptoms resolved spontaneously.

The allergology workup was repeated in order to assess whether the patient was a cross-intolerant or a selective reactor to both ibuprofen and diclofenac. Controlled administration of ASA was started after the initial reaction as described above, and tolerance was confirmed. The results of the skin prick test $(25 \mathrm{mg} / \mathrm{mL})$ and intradermal test $(1 \mathrm{mg} / \mathrm{mL}$ and $2.5 \mathrm{mg} / \mathrm{mL})$ to diclofenac were negative. We did not carry out a drug provocation test using diclofenac, since the patient had reported 2 consecutive anaphylactic episodes with this drug (the second episode was severe). The results of the skin test were positive for house dust mite and grass and olive pollen and negative for a battery of food allergens including Pru p 3.

Clinical evidence indicates that cross-reactivity can occur in selective responses to arylpropionic acid derivatives [8]. Therefore, avoidance of ibuprofen and other arylpropionic acid derivatives was recommended, as was avoidance of arylacetic acid derivatives including diclofenac and aceclofenac. The patient was able to tolerate ASA and other NSAIDs, as well as selective COX-2 inhibitors.

NSAIDs are consumed worldwide by people of all ages [1,9]. Allergic reactions have been reported for both children and adults [7,9]. Given the lack of alternatives, when patients report reactions to NSAIDs, a study is required to establish diagnosis and provide other drugs [3]. Within crossintolerant patients, mainly those with NIUA and NERD, the first approach is to verify tolerance to ASA. If the response is positive, the procedure is to avoid all strong COX-1 inhibitors and test weak COX-1 inhibitors such as meloxicam and paracetamol, if tolerance to these is not known. Testing is recommended because, although these drugs are usually well tolerated, a low percentage of patients may experience reactions to them.

Given that the patient tolerated ASA in the first workup, he was diagnosed as having experienced a selective anaphylactic_-presumably IgE-mediated-response to ibuprofen. After this episode, the patient took a COX-1 inhibitor (ie, diclofenac) at full therapeutic doses on several occasions and ASA at low therapeutic doses for prophylaxis of cardiovascular disease.

The subsequent intake of diclofenac derivatives by different routes increased the possibility of sensitization. When the patient experienced 2 consecutive episodes to diclofenac, a selective immediate reaction was suspected, as recently reported [10]. The administration of ASA up to a full therapeutic dose ruled out the possibility that the patient was cross-intolerant. Therefore, we conclude that he presented 2 separate unrelated specific allergic drug reactions rather than cross-intolerance to NSAIDs.

According to the recently proposed classification of hypersensitivity to NSAIDs [2], this patient should be classified in the NIUA category of cross-intolerance, since he had experienced several immediate reactions to various NSAIDs. However, as tolerance to ASA was proven, we must classify this case as a selective response to various NSAIDs [4].

Our findings point to a potentially new phenotype of hypersensitivity to NSAIDs. Patients who experience allergic reactions to a given NSAID can develop selective reactions to others, and the administration of ASA is mandatory to rule out cross-reactions. There is a possibility that patients can react to even more than 2 chemically unrelated NSAIDs and that different immunological mechanisms may be implicated for each drug. The prevalence of this type of hypersensitivity is currently unknown.

\section{Funding}

JA Cornejo-García is funded by the Miguel Servet Program (Ref CP14/00034) and JR Perkins by the Sara Borrell Program (Ref CD14/00242) (Carlos III National Health Institute, Spanish Ministry of Economy and Competitiveness). This study was supported by grants from the Carlos III National Health Institute RD12/0013 (RIRAAF network), FIS (PI12/02247, PI13/02598, and PI15/00726), and the Andalusian Health Service (PI-0279-2012).

This work was supported by grants from the European Regional Development's Funds (FEDER).

\section{Conflicts of Interest}

The authors declare that they have no conflicts of interest.

\section{References}

1. Doña I, Blanca-Lopez N, Torres MJ, Garcia-Campos J, GarciaNuñez I, Gomez F, Salas M, Rondón C, Canto G, Blanca M. Drug hypersensitivity reactions: response patterns, drug involved, and temporal variations in a large series of patients. J Investig Allergol Clin Immunology. 2012;22:363-71.

2. Kowalski ML, Asero R, Bavbek S, Blanca M, Blanca-Lopez N, Bochenek G, Brockow K, Campo P, Celik G, Cernadas J, Cortellini G, Gomes E, Nizankowska-Mogilnicka E, Romano A, Szczeklik A, Testi S, Torres MJ, Wohrl S, Makowska J. Classification and practical approach to the diagnosis 
and management of hypersensitivity to nonsteroidal antiinflammatory drugs. Allergy. 2013;68:1219-32.

3. Cornejo-Garcia JA, Blanca-Lopez N, Doña I, Andreu I, Agundez JA, Carballo M, Blanca M, Canto MG. Hypersensitivity reactions to non-steroidal anti-inflammatory drugs. Current Drug Metabolism. 2009;10:971-80.

4. Demir S, Olgac M, Unal D, GelincikA, Colakoglu B, Buyukozturk S. Evaluation of hypersensitivity reactions to nonsteroidal anti-inflammatory drugs according to the latest classification. Allergy. 2015;70:1461-7.

5. Cavkaytar O, Arik Yilmaz E, Karaatmaca B, Buyuktiryaki B, Sackesen C, Sekerel BE, Soyer O. Different Phenotypes of Non-Steroidal Anti-Inflammatory Drug Hypersensitivity during Childhood. Int Arch Allergy Immunol. 2015;167:211-21.

6. Ayuso P, Blanca-Lopez N, Doña I, Torres MJ, Gueant-Rodriguez RM, Canto G, Sanak M, Mayorga C, Guéant JL, Blanca M, Cornejo-García JA. Advanced phenotyping in hypersensitivity drug reactions to NSAIDs. Clin Exp Allergy. 2013;43:1097109.

7. Doña I, Blanca-Lopez N, Cornejo-Garcia JA, Torres MJ, Laguna JJ, Fernandez J, Rosado A, Rondón C, Campo P, Agúndez JA, Blanca M, Canto $G$. Characteristics of subjects experiencing hypersensitivity to non-steroidal anti-inflammatory drugs: patterns of response. Clin Exp Allergy. 2011;41:86-95.

8. Blanca-López N, Pérez-Alzate D, Andreu I, Doña I, Agúndez JA, García-Martín E, Salas M, Miranda MA, Torres MJ, CornejoGarcía JA, Canto G, Blanca M. Immediate hypersensitivity reactions to ibuprofen and other arylpropionic acid derivatives. Allergy 2016 Feb 3. doi: 10.1111/all.12855. [Epub ahead of print] PubMed PMID: 26841325.

9. Blanca-López N, Cornejo-García JA, Plaza-Serón $M C_{\text {, }}$ Doña I,Torres-Jaén MJ, Canto G, Padilla-España L, Kidon M, Perkins JR, Blanca M. Hypersensitivity to nonsteroidal anti-inflammatory drugs in children and adolescents: crossintolerance reactions. J Investig Allergol Clin Immunol. 2015;25:94-106.

10. Picaud J, Beaudouin E, Renaudin JM, Pirson F, Metz-Favre C, Dron-Gonzalvez M, Moneret-Vautrin DA. Anaphylaxis to diclofenac: nine cases reported to the Allergy Vigilance Network in France. Allergy. 2014;69:1420-3.

- Manuscript received December 14, 2015; accepted for publication March 15, 2016.

\section{Disseminated BCG Infectious Disease and Hyperferritinemia in a Patient With a Novel NEMO Mutation}

Karaca $\mathrm{NE}^{1}$, Aksu $\mathrm{G}^{1}$, Ulusoy $\mathrm{E}^{1}$, Cavusoglu $\mathrm{C}^{2}$, Oleaga-Quintas $\mathrm{C}^{3,4}$, Nieto-Patlan $\mathrm{A}^{3,4}$, Richard $\mathrm{ME}^{3,4}$, Deswarte $\mathrm{C}^{3,4}$, Casanova $\mathrm{JL}^{3,4,5,6,7}$, Bustamante $\mathrm{J}^{3,4,5,8 *}$, Kutukculer $\mathrm{N}^{1 *}$

${ }^{1}$ Ege University School of Medicine, Department of Pediatrics, Division of Pediatric Immunology, Izmir, Turkey

${ }^{2}$ Ege University Faculty of Medicine, Department of Microbiology, Izmir, Turkey

${ }^{3}$ Laboratory of Human Genetics of Infectious Diseases, Necker Branch, INSERM U1163, Imagine Institute, Necker Hospital for Sick Children, Paris, France

${ }^{4}$ Paris Descartes University, Paris, France

${ }^{5}$ St. Giles Laboratory of Human Genetics of Infectious Diseases, Rockefeller Branch, The Rockefeller University, New York, USA ${ }^{6}$ Howard Hughes Medical Institute, New York, USA

${ }^{7}$ Pediatric Hematology-Immunology Unit, Assistance PubliqueHopitaux de Paris AP-HP, Necker Hospital for Sick Children, Paris, France

${ }^{8}$ Center for the Study of Primary Immunodeficiencies, Assistance Publique-Hôpitaux de Paris AP-HP, Necker Hospital for Sick Children, Paris, France

* Both authors contributed equally to the manuscript.

J Investig Allergol Clin Immunol 2016; Vol. 26(4): 268-271 doi: $10.18176 /$ jiaci.0068

Key words: BCG-osis. Interferon. Hyperferritinemia. NEMO mutation. Ectodermal dysplasia.

Palabras clave: BCGosis. Interferón. Hiperferritinemia. Mutación en NEMO. Displasia ectodérmica.

Hypomorphic mutations of the nuclear factor $\kappa \mathrm{B}$ essential modulator gene $(N E M O)$ result in a wide range of clinical phenotypes, including ectodermal dysplasia (EDA) with immunodeficiency and Mendelian susceptibility to mycobacterial disease [1-3]. Mycobacterial infectious diseases are reported in about $40 \%$ of patients with the NEMO mutation [1-3]. We report a patient with a novel $N E M O$ mutation who presented with disseminated mycobacterial infection leading to increased ferritin levels with no signs of EDA.

The patient was born in 2011 to nonconsanguineous Turkish parents. He received BCG vaccine at 2 months of age. At 5 months, he had bronchiolitis, and at 8 months, he was admitted to hospital with fever, generalized lymphadenopathy, and hepatosplenomegaly. His weight was $6590 \mathrm{~g}\left(3^{\text {rd }}-10^{\text {th }}\right.$ percentile) and his height was $63 \mathrm{~cm}\left(3^{\text {rd }}-10^{\text {th }}\right.$ percentile $)$. Liver and lymph node biopsies revealed tuberculoid granuloma with multiple bacilli (Figure, A). The result of PCR was positive for Mycobacterium bovis complex. Bone marrow aspirate smear and biopsy findings were normal. Laboratory examinations disclosed the following values: white blood cells, 14 000/ $\mathrm{mm}^{3}$ (52\% neutrophils, 38\% lymphocytes, 
$4 \%$ monocytes, and 6\% eosinophils); hemoglobin $(\mathrm{Hb})$, $8.2 \mathrm{~g} / \mathrm{dL}$; hematocrit (Htc), 26.6\%; platelets, $386000 / \mathrm{mm}^{3}$; C-reactive-protein (CRP), $25 \mathrm{mg} / \mathrm{dL}$; and erythrocyte sedimentation rate (ESR), $140 \mathrm{~mm} / \mathrm{h}$. Biochemistry findings were normal except for elevated ferritin levels $(1160 \mu \mathrm{g} / \mathrm{dL})$, total protein $(8.2 \mathrm{~g} / \mathrm{dL})$, and albumin $(2.8 \mathrm{~g} / \mathrm{dL})$. Analysis of lymphocyte subsets revealed CD $3^{+} \mathrm{T}$ cells $\left(82 \%, 4360 / \mathrm{mm}^{3}\right)$, CD $19^{+} \mathrm{B}$ cells $\left(14 \%, 744 / \mathrm{mm}^{3}\right), \mathrm{CD}^{+} \mathrm{CD}^{+}$helper T cells $(14 \%$, $\left.610 / \mathrm{mm}^{3}\right), \mathrm{CD}^{+} \mathrm{CD}^{+}$cytotoxic T cells $\left(67 \%, 2922 / \mathrm{mm}^{3}\right)$, and CD3-CD $16^{+} / 56^{+}$natural killer cells $\left(2 \%, 106 / \mathrm{mm}^{3}\right)$. Severe combined immunodeficiency was ruled out. The oxidative burst was normal, thus ruling out chronic granulomatous disease. Ig levels were as follows: $\operatorname{IgG}, 2640 \mathrm{mg} / \mathrm{dL}$; IgM, $145 \mathrm{mg} / \mathrm{dL}$; IgA, $20 \mathrm{mg} / \mathrm{dL}$; IgE, $2.8 \mathrm{kU}$ A $/ \mathrm{L}$ (age-related normal values; IgG 692 [181] mg/dL, IgA 52 [36] mg/dL, IgM 86 [40] mg/dL, IgE $<100 \mathrm{kU}_{\mathrm{A}} / \mathrm{L}$, respectively) [4]. Viral and parasitic serology testing, including serology for human immunodeficiency virus, were negative. Thus, the patient was diagnosed with disseminated BCG disease (BCG-osis), and a defect in the IFN- $\gamma$ pathway was suspected. Treatment was started with isoniazid, clarithromycin, and rifabutin, together with subcutaneous recombinant IFN- $\gamma$. During follow-up, the patient gained weight and began to walk; lymphoproliferative disorder and hepatosplenomegaly regressed. Acute phase reactant levels remained high, with gradually increasing ferritin levels despite the patient's good clinical condition. IgG levels decreased, whereas $\operatorname{IgM}$ gradually increased 8 months after the first admission. The patient was admitted to hospital with darkening of the skin, fatigue, and inability to walk at 2 years of age during antimycobacterial treatment. He failed to thrive in the absence of chronic diarrhea. He had brownish skin, coarse hair, and hepatosplenomegaly. Laboratory examinations disclosed the following values: $\mathrm{WBC}, 6460 / \mathrm{mm}^{3} ; \mathrm{Hb}, 6.4 \mathrm{~g} / \mathrm{dL}$; Htc, $23.3 \%$; platelets, $232,000 / \mathrm{mm}^{3}$; CRP, $15 \mathrm{mg} / \mathrm{dL}$; ESR, $120 \mathrm{~mm} / \mathrm{h}$; serum iron, $23 \mu \mathrm{g} / \mathrm{dL}$; total iron binding capacity, $262 \mu \mathrm{g} / \mathrm{dL}$; ferritin, 14 300, $\mu \mathrm{g} / \mathrm{dL}$; IgG, $694 \mathrm{mg} / \mathrm{dL}$; IgM, $481 \mathrm{mg} / \mathrm{dL}$; and IgA, $<5.6 \mathrm{mg} / \mathrm{dL}$. Although the patient did not have fever, bone marrow aspirate biopsy was performed to rule out hemophagocytic lymphohistiocytosis because of high levels of plasma ferritin and anemia. A liver biopsy excluded iron deposition in hepatocytes. Cranial MRI revealed no iron deposition in the brain (Figure, B). A 1-year multidrug
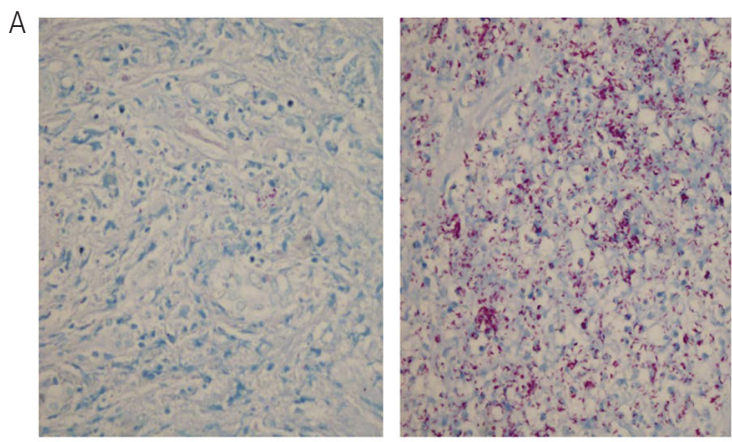

D
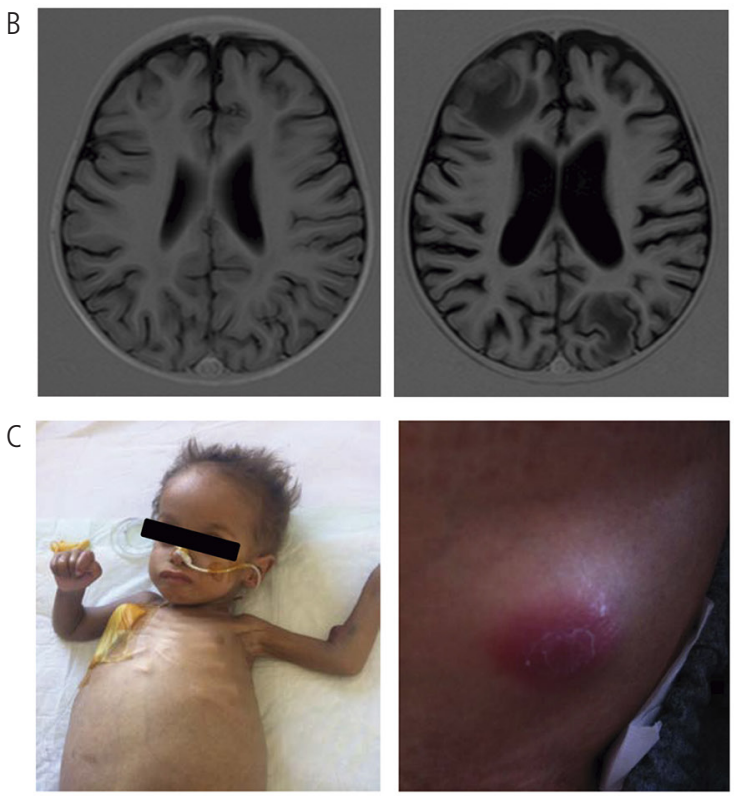

Wild type

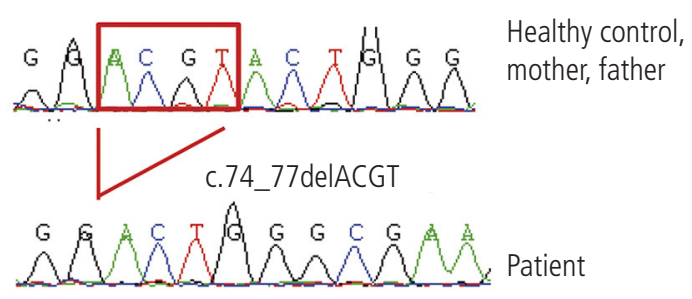

$E$

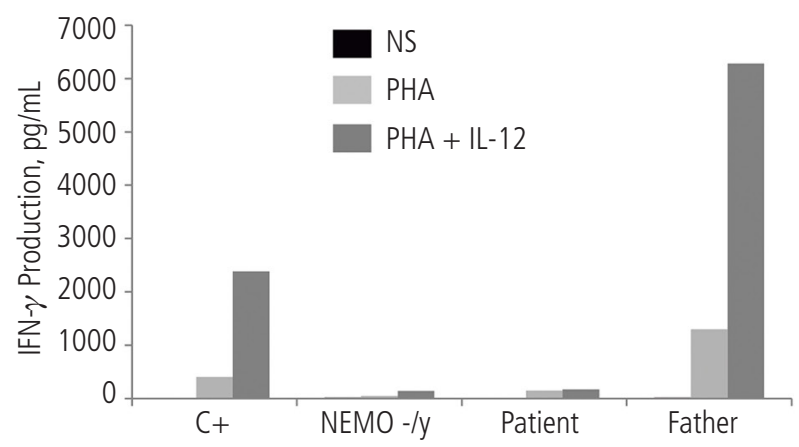

Figure. Disseminated mycobacterial infections and NEMO deficiency. A, Acid-fast stained mycobacteria appeared as purple rods within hepatocytes in a Ziehl-Neelsen stain (left, at 8 months of age; right, at 2 years of age). B, T1-weighted magnetic resonance image of the brain (left, normal; right, multiple ring-enhancing lesions), with surrounding edema, consistent with an abscess in the cerebral hemispheres. C, Protruding cutaneous lesions on the arm and left lumbar region. D, Electropherograms of a wild-type NEMO carrier (healthy control and both parents) and the patient. E, Production of IFN- $\gamma$ after activation of peripheral blood mononuclear cells from a healthy control, a NEMO-deficient patient, the patient, and the patient's father. 
antimycobacterial regimen and IFN- $\gamma$ could not stop disease progression, and treatment was started with streptomycin, pyrazinamide, and azithromycin, together with intravenous immunoglobulin. Corticosteroid therapy was started in order to manage suspected noninfectious persistent systemic inflammation. However, the response was poor, and the drugs were discontinued. Liver biopsy revealed granulomatous hepatitis associated with BCG-osis. Subcutaneous nodules appeared (Figure, C), and bacille Calmette-Guérin was isolated from the fluid drained from the lesions. The patient experienced an afebrile tonic seizure, and cranial MRI showed multiple ring-enhancing lesions with surrounding edema consistent with abscesses in both cerebral hemispheres and indicating central involvement of disseminated mycobacterial infection (Figure, B). Informed consent was obtained from the patient's parents, and all studies were performed with the approval of our respective institutional review boards. Whole-exome sequencing identified a novel hemizygous mutation in exon 2 of NEMO (c.74_77delACGT), resulting in a frameshift (Figure, D). This mutation was confirmed by Sanger sequencing and was not found in any of the public databases or in our in-house cohort. Both parents carried the wild type, suggesting that it was a de novo mutation. Examination of peripheral blood mononuclear cells from the patient revealed impaired production of IFN- $\gamma$ (Figure, E) and absence of IL-12p70 (data not shown). Unfortunately, the lack of biological material prevented us from studying the impact of the mutation in terms of protein expression and mRNA level. Increased IgM and decreased IgG levels were thought to be a probable Ig class switch recombination defect. The mutation did not display signs of EDA, and skin biopsy confirmed the presence of sweat glands and a normal epidermis and dermis. Despite robust antimycobacterial treatment, the patient died from multiorgan failure due to BCG-osis.

$\mathrm{BCG}$ vaccine is administered to newborns in countries that are endemic for tuberculosis. Patients with severe combined immunodeficiency, chronic granulomatous disease, and Mendelian susceptibility to mycobacterial disease can develop BCG-osis, with high rates of mortality $[2,5]$. Abnormal immunoglobulin production and absence of serum antibodies against carbohydrates have been observed in NEMO-deficient patients [1]. The patient we report on here had hypergammaglobulinemia on admission and increasing $\operatorname{IgM}$ levels and decreasing $\operatorname{IgG}$ and $\operatorname{IgA}$ levels with age, suggesting a class switch recombination defect. The specific antibody response could not be evaluated owing to periodic replacement of intravenous immunoglobulin. As observed in some patients with hypomorphic NEMO mutations, the patient we report on here produced low levels of IFN- $\gamma$ but not IL-12p70 [6,7]. Overexpression experiments could explain the mechanism of this new mutation, which is probably a reinitiation of translation similar to those reported previously [3].

The elevated ferritin concentrations were remarkable. Such elevations are observed in some types of cancer, systemic onset juvenile rheumatoid arthritis, multiple erythrocyte transfusions, and hemophagocytic lymphohistiocytosis [8-10]. The patient received erythrocyte suspensions twice for anemia during follow-up, and transfusion-related liver iron accumulation was excluded by histopathology and MRI. A causal relationship with hyperferritinemia has not been defined for intrinsic molecular defects of the NEMO mutation. The high levels of ferritin were probably caused by the high inflammatory response due to BCG-osis. High levels of plasma ferritin, which are a marker of systemic inflammation, can accompany disseminated mycobacterial disease.

\section{Acknowledgments}

We wish to thank Yelena Nemirovskaya and Lahouari Amar for their administrative support.

\section{Funding}

This research was funded in part by a grant from the National Institute of Allergy and Infectious Diseases (grant number 5R01AI089970), the National Center for Research Resources and the National Center for Advancing Sciences of the National Institutes of Health (grant number 8UL1TR000043), The Rockefeller University, the St. Giles Foundation, Institut National de la Santé et de la Recherche Médicale (INSERM), Paris Descartes University, Laboratoire d'Excellence Integrative Biology of Emerging Infectious Diseases (ANR-10-LABX-62-IBEID), and the French National Research Agency (ANR) under the "Investments for the future" program (grant number ANR-10-IAHU-01).

\section{Conflicts of Interest}

The authors declare that they have no conflicts of interest.

\section{References}

1. Picard C, Casanova JL, Puel A. Infectious diseases in patients with IRAK-4, MyD88, NEMO, or $\mid \kappa$ B $\alpha$ deficiency. Clin Microbiol Rev. 2011;24:490-7.

2. Bustamante J, Boisson-Dupuis S, Abel L, Casanova JL. Mendelian susceptibility to mycobacterial disease: genetic, immunological, and clinical features of inborn errors of IFN- $\nabla$ immunity. Semin Immunol. 2014;26:454-70.

3. Puel $A$, Reichenbach J, Bustamante J, $\mathrm{Ku} \mathrm{CL}$, Feinberg J, Döffinger $R$, Bonnet $M$, Filipe-Santos $O$, de Beaucoudrey L, Durandy A, Horneff G, Novelli F, Wahn V, Smahi A, Israel $A$, Niehues T, Casanova JL. The NEMO mutation creating the most-upstream premature stop codon is hypomorphic because of a reinitiation of translation. Am J Hum Genet. 2006;78:691-701.

4. Aksu G, Genel F, Koturoglu G, Kurugol Z, Kutukculer N. Serum immunoglobulin ( $\lg G, \lg M, \lg A)$ and $\lg G$ subclass concentrations in healthy children: a study using nephelometric technique. Turk J Pediatr. 2006;48:19-24.

5. Marciano $B E$, Huang $C Y$, Joshi $G$, Rezaei $N$, Carvalho $B C$, Allwood Z, Ikinciogullari A, Reda SM, Gennery A, Thon V, Espinosa-Rosales F, Al-Herz W, Porras O, Shcherbina A, Szaflarska A, Kiliç Ş, Franco JL, Gómez Raccio AC, Roxo P Jr, Esteves I, Galal N, Grumach AS, Al-Tamemi S, Yildiran A, Orellana JC, Yamada M, Morio T, Liberatore D, Ohtsuka Y, Lau YL, Nishikomori R, Torres-Lozano C, Mazzucchelli JT, Vilela MM, Tavares FS, Cunha L, Pinto JA, Espinosa-Padilla SE, Hernandez-Nieto L, Elfeky RA, Ariga T, Toshio H, Dogu 
$F$, Cipe F, Formankova $R$, Nuñez-Nuñez ME, Bezrodnik $L$, Marques JG, Pereira MI, Listello V, Slatter MA, Nademi Z, Kowalczyk D, Fleisher TA, Davies G, Neven B, Rosenzweig SD. BCG vaccination in patients with severe combined immunodeficiency: complications, risks, and vaccination policies. J Allergy Clin Immunol. 2014;133:1134-41.

6. Haverkamp MH, Marciano BE, Frucht DM, Jain A, van de Vosse E, Holland SM. Correlating interleukin-12 stimulated interferon- $\gamma$ production and the absence of ectodermal dysplasia and anhidrosis (EDA) in patients with mutations in NF- $\kappa$ B essential modulator (NEMO). J Clin Immunol. 2014;34(4):436-43.

7. Filipe-Santos $\mathrm{O}$, Bustamante J, Haverkamp MH, Vinolo $\mathrm{E}, \mathrm{Ku}$ $C L$, Puel $A$, Frucht DM, Christel $K$, von Bernuth $H$, Jouanguy E, Feinberg J, Durandy A, Senechal B, Chapgier A, Vogt G, de Beaucoudrey L, Fieschi C, Picard C, Garfa M, Chemli J, Bejaoui M, Tsolia MN, Kutukculer N, Plebani A, Notarangelo $L$, Bodemer C, Geissmann F, Israël A, Véron M, Knackstedt $M$, Barbouche R, Abel L, Magdorf K, Gendrel D, Agou F, Holland SM, Casanova JL. X-linked susceptibility to mycobacteria is caused by mutations in NEMO impairing CD40-dependent IL12 production. J Exp Med. 2006;203(7):1745-59.

8. Moore C Jr, Ormseth M, Fuchs $H$. Causes and significance of markedly elevated serum ferritin levels in an academic medical center. J Clin Rheumatol. 2013;19:324-8.

9. Pachlopnik Schmid JM, Junge SA, Hossle JP, Schneider EM, Roosnek E, Seger RA, Gungor T. Transient hemophagocytosis with deficient cellular cytotoxicity, monoclonal immunoglobulin M gammopathy, increased T-cell numbers, and hypomorphic NEMO mutation. Pediatrics. 2006;117:1049-56.

10. Manoj EM, Srigrishna R, Ragunathan MK. Hepatic tubersulosis presenting with extreme hyperferritinemia masquerading as adult-onset Still's disease: a case report. J Med Case Rep. 2012;6:195.

Manuscript received December 12, 2015; accepted for publication April 1, 2016.

Neslihan Edeer Karaca E-mail: Neslihanedeer@gmail.com

Jacinta Bustamante

E-mail: jacinta.bustamante@inserm.fr

\section{Experience With Rapid Desensitization to Chemotherapy in a Type B Hospital}

Borras J ${ }^{1}$, El-Qutob D ${ }^{2}$

${ }^{1}$ Allergy Unit, Consorcio Hospitalario Provincial de Castellón, Castellón, Spain

${ }^{2}$ Allergy Unit, Hospital Universitario de La Plana, Vila-Real, Spain

J Investig Allergol Clin Immunol 2016; Vol. 26(4): 271-273 doi: $10.18176 /$ jiaci.0070

Key words: Chemotherapy. Desensitization. Drug allergy. Taxans. Platinum salts.

Palabras clave: Quimioterapia. Desensibilización. Alergia a fármacos. Taxanos. Sales de platino.

Hypersensitivity reactions (HSRs) to monoclonal antibodies and chemotherapy can lead to the discontinuation of first-line therapy and replacement by alternative agents that are often less effective, more toxic, and/or more expensive, leading to decreased quality of life and life expectancy [1]. The purpose of this article is to present our experience with desensitization protocols in patients with HSRs to chemotherapy in a type B hospital.

Between May 2008 and April 2015, patients with suspected HSRs to chemotherapy were referred to the allergy department for evaluation of rapid desensitization. The inclusion criteria were ability to give informed consent and a strong suspicion of an immediate or delayed moderate to severe HSR to platinum salts, trastuzumab, or paclitaxel with or without a positive skin test. Patients with serum sickness, DRESS (Drug Rash with Eosinophilia and Systemic Syndrome), Stevens-Johnson syndrome, or toxic epidermal necrolysis were excluded. The concentrations used for platinum salts were based on the protocol of Castells et al [2]. Trastuzumab was tested at $0.5 \mathrm{mg} / \mathrm{mL}$ for skin prick and intradermal tests. Paclitaxel skin tests were carried out using previously described methods [3].

Before desensitization, patients had to follow premedication at home with montelukast $10 \mathrm{mg}$, acetylsalicylic acid $300 \mathrm{mg}$, ebastine $10 \mathrm{mg}$, ranitidine $150 \mathrm{mg}$, and oral diazepam $5 \mathrm{mg}$. At hospital, they received intravenous (IV) ranitidine, dexchlorpheniramine IV, and sublingual diazepam $5 \mathrm{mg}$, in addition to the pretreatment prescribed by their oncologists (dexamethasone IV and granisetron IV). $\beta$-Blockers were withheld for 24 hours before desensitization. In all cases, initial desensitization was carried out at the hospital's intensive care unit. Subsequent desensitizations were conducted at the outpatient infusion center or on an inpatient ward. The interval between chemotherapy treatments was 3 to 4 weeks, following standard oncology protocols. We used the 12-step protocol published by Castells et al [2]. In low-risk patients or patients who had previously tolerated a desensitization procedure, infusion was accelerated in the final step of the protocol and the total duration was just 4.5 hours. 
The initial HSRs observed were syncope (5.5\% of patients), hypotension (12.8\%), dyspnea (23.8\%), gastrointestinal symptoms (nausea/vomiting/ diarrhea/abdominal pain) $(17.4 \%)$, and cutaneous manifestations $(40.3 \%)$.

A total of 281 rapid desensitizations were performed using the 12-step protocol published by Castells et al [2] in 53 patients being treated for a malignancy. All the desensitizations were administered intravenously; $43.4 \%$ of the patients were desensitized to carboplatin (131 desensitizations), 37.7\% to oxaliplatin $(n=79)$, and $16.9 \%$ to paclitaxel $(n=42)$. In addition, 1 patient was desensitized to trastuzumab $(n=29)$. All 53 patients were initially desensitized in the intensive care unit. Subsequently, 228 desensitizations were conducted on the inpatient ward or in the outpatient infusion center. Only $15 \%$ of desensitizations elicited a reaction. Thirty-nine percent of patients $(n=21)$ developed a reaction. Fifty-five reactions occurred during 44 desensitizations, with some patients experiencing more than 1 reaction during a single procedure. The reactions were usually mild, and only $11 \%(n=5)$ were of moderate severity (eg, hypotension and dyspnea). They were all brought under control by stopping the infusion and administering antihistamines. Epinephrine was not necessary in any of the cases, even in patients who developed dyspnea and hypotension. All the patients had received the full therapeutic dose by the end of procedure and only 3 patients required modifications to the infusion rate indicated by the protocol. No reactions occurred during the infusion of solution A (steps 1-4), 20\% occurred during the infusion of solution B (steps 5-8), and 74.5\% occurred during the infusion of solution C (steps 9-12). Three reactions were delayed (maculopapular rash) but they all occurred in the next 24 hours (mostly within 2-3 hours) of desensitization.

All the patients needed multiple desensitizations and the majority of reactions occurred during the first 3 desensitizations (30 [68\%]). Both the frequency and severity of reactions decreased with subsequent courses.

In 2005, Feldweg et al [4] described 77 desensitization procedures with paclitaxel and docetaxel, and reported a success rate of $93.5 \%$ ( 72 procedures) using a desensitization protocol that lasted 6 to 7 hours. In our series, the patients developed a reaction during paclitaxel desensitization in $9.5 \%$ of cases but the desensitization took approximately 4.5 hours. The number and severity of reactions during our desensitization procedures were similar to those reported by Castells et al [2]. Moreover, in both cases, the majority of reactions occurred during the first desensitization. MadrigalBurgaleta et al [5] published a study of 189 intravenous rapid desensitizations in 2013. There were no reactions in $94 \%$ of cases, and $69 \%$ of the reactions that occurred were observed during the infusion of solution $C$ (steps 9-10). These results are similar to ours except that we observed a lower percentage of reactions in the final steps of the protocol, probably because of the lower dose used in the 10-step protocol described by Madrigal-Burgaleta et al. In fact, the starting dose of their protocol is 80 -fold higher than the one used in the 12-step protocol, and this constitutes a potential risk for reactions in the intermediate steps (5-8) and not during the first steps (1-4), when reactions were only observed in $0.5 \%$ of 189 desensitizations. Other authors have published small series of successful desensitization procedures with trastuzumab, docetaxel, rituximab, infliximab, and cetuximab [6,7]. In 2011, Gastaminza et al [8] used a 5-step protocol based on 5 ten-fold dilutions of the drugs, and only 3 patients presented a reaction $(7.2 \%)$ in 39 procedures. However, 1 patient did not reach the final therapeutic dose.

Similar success rates have been described for 5-, 10- and 12-step desensitization protocols, but the protocols do not differ greatly, since most of the drug is administered in the last step in all methods. In our protocol and that described by Castells et al, $92 \%$ of the total dose was administered in the last step, which lasted 2 to 3 hours [9]. In the protocol described by Gastaminza et al [8], 89\% of the total drug dose was delivered in the last step, over a period of 1 hour. In the Madrigal-Burgaleta protocol by contrast, just $84.6 \%$ of the therapeutic dose is administered, over 135 minutes, in the last 2 steps [10]. The varying results may have been influenced by differences in the number of patients with severe reactions included in the studies.

In conclusion, based on our experience, rapid desensitization is a safe and effective method that can be performed in different type of hospitals.

\section{Acknowledgments}

We would like to thank all the staff at the hospital's intensive care unit and Outpatient Oncology Clinic.

\section{Funding}

The authors declare that no funding was received for the present study.

\section{Conflicts of Interest}

The authors declare that they have no conflicts of interest.

\section{References}

1. Castells Guitart MC. Rapid drug desensitization for hypersensitivity reactions to chemotherapy and monoclonal antibodies in the 21st century. J Investig Allergol Clin Immunol. 2014;24(2):72-9; quiz 2 p following 9.

2. Castells MC, Tennant NM, Sloane DE, Hsu FI, Barrett NA, Hong DI, Laidlaw TM, Legere HJ, Nallamshetty SN, Palis RI, Rao JJ, Berlin ST, Campos SM, Matulonis UA. Hypersensitivity reactions to chemotherapy: outcomes and safety of rapid desensitization in 413 cases. J Allergy Clin Immunol. 2008 Sep;122(3):574-80.

3. Prieto Garcia A, Pineda de la Losa F. Immunoglobulin E-mediated severe anaphylaxis to paclitaxel. J Investig Allergol Clin Immunol. 2010;20(2):170-1.

4. Feldweg AM, Lee CW, Matulonis UA, Castells M. Rapid desensitization for hypersensitivity reactions to paclitaxel and docetaxel: a new standard protocol used in 77 successful treatments. Gynecol Oncol. 2005 Mar;96(3):824-9.

5. Madrigal-Burgaleta $R$, Berges-Gimeno MP, Angel-Pereira D, Ferreiro-Monteagudo R, Guillen-Ponce C, Pueyo C, Gomez de Salazar E, Alvarez-Cuesta E. Hypersensitivity and desensitization to antineoplastic agents: outcomes of 189 
procedures with a new short protocol and novel diagnostic tools assessment. Allergy. 2013 Jul;68(7):853-61.

6. Cavazos Galvan M, Villarreal Cardenas JR. Rapid desensitization to chemotherapy drugs in oncologic patients. A good and safe option. A two-case presentation. Rev Alerg Mex. 2010 May-June;57(3):99-103.

7. Hong Dl, Bankova L, Cahill KN, Kyin T, Castells MC. Allergy to monoclonal antibodies: cutting-edge desensitization methods for cutting-edge therapies. Expert review of clinical immunology. 2012 Jan;8(1):43-52; quiz 3-4.

8. Gastaminza G, de la Borbolla JM, Goikoetxea MJ, Escudero R, Anton J, Espinos J, Lacasa C, Fernandez-Benitez M, Sanz $\mathrm{ML}$, Ferrer M. A new rapid desensitization protocol for chemotherapy agents. J Investig Allergol Clin Immunol. 2011;21(2):108-12.

9. Lee CW, Matulonis UA, Castells MC. Rapid inpatient/ outpatient desensitization for chemotherapy hypersensitivity: standard protocol effective in 57 patients for 255 courses. Gynecol Oncol. 2005 Nov;99(2):393-9.

10. Belperio JA, Keane MP, Burdick MD, Londhe V, Xue YY, Li K, Phillips RJ, Strieter RM. Critical role for CXCR2 and CXCR2 ligands during the pathogenesis of ventilator-induced lung injury. J Clin Invest. 2002 Dec;110(11):1703-16.

Manuscript received February 10, 2016; accepted for publication April 5, 2016

David El-Qutob

Unidad de Alergia Hospital Universitario de La Plana Carretera Vila-Real-Burriana Km. 0.5 Vila-Real 12540, Spain E-mail: elqutob@comv.es

\section{Delayed Allergic Reaction to Acenocoumarol With a Positive Lymphocyte Transformation Test}

Dominguez-Ortega $\mathrm{J}^{1,3,4}$, Entrala $\mathrm{A}^{1}$, Pola-Bibian $\mathrm{B}^{1}$, GonzalezMuñoz $\mathrm{M}^{2}$, Fiandor $\mathrm{A}^{1,3}$, Quirce $\mathrm{S}^{1,3,4}$

${ }^{1}$ Department of Allergy, Hospital La Paz, Madrid, Spain

${ }^{2}$ Department of Immunology, Hospital La Paz, Madrid, Spain

${ }^{3}$ Hospital La Paz Institute for Health Research (IdiPAZ)

${ }^{4}$ CIBER de Enfermedades Respiratorias, Ciberes, Madrid, Spain

J Investig Allergol Clin Immunol 2016; Vol. 26(4): 273-275 doi: 10.18176/jiaci.0072

Key words: Acenocoumarol. Allergy. Delayed reaction. Lymphocyte transformation test.

Palabras clave: Acenocumarol. Alergia. Reacción retardada. Test de transformación linfoblástica.

Acenocoumarol is one of the most commonly used coumarin anticoagulants in the prevention and treatment of thromboembolic complications. These drugs exert their pharmacological effect by interfering with the recycling of vitamin $\mathrm{K}$ and inhibiting the subsequent activation of coagulation factors [1]. Although adverse effects are frequent, most of them are associated with overdosage and potential interacting medications. Selective hypersensitivity reactions to this drug, by contrast, are extremely rare. Cutaneous necrosis induced by acenocoumarol has been previously described [2], but it is infrequent $(0.01 \%-0.1 \%$ of patients on anticoagulant treatment). There have also been isolated reports of atypical calciphylaxis [3], Henoch-Schönlein purpura [4], leukocytoclastic vasculitis [5], and DRESS (drug reaction with eosinophilia and systemic symptoms syndrome) [6]. Although acenocoumarol was identified as the agent responsible for all these adverse reactions due to the favorable clinical outcome on withdrawal of the anticoagulant, causality between the drug and the reactions was not objectively assessed either in vivo or in vitro.

We present the case of an 81-year-old man, an exsmoker, with hypertension, dyslipidemia, chronic ischemic heart disease with ventricular systolic dysfunction, morbid obesity, and obstructive sleep apnea syndrome treated with bilevel positive airway pressure, who was hospitalized for a heart attack. Catheterization with contrast was performed. During hospitalization the patient presented paroxysmal atrial fibrillation and was administered drugs that he had not been previously taking, namely, acenocoumarol, (Sintrom, Novartis Farmacéutica S.A.), enalapril, eplerenone, and bisoprolol. On day 4, 30 minutes after taking the daily dose $(4 \mathrm{mg})$ of acenocoumarol, he experienced an episode of micropapular itchy rash on the trunk and limbs, tending to merge onto the trunk. No oral or other mucosal involvement was observed and there were no pustules, vesicles, or blisters. Eosinophilia, enlarged lymph nodes, elevated creatinine, and hepatitis were not observed. He was treated first with $5 \mathrm{mg}$ of intravenous 
dexchlorpheniramine maleate, oral antihistamines, topical steroids and withdrawal of acenocoumarol, resulting in complete resolution of the reaction in 3 days. He continued with the rest of the medication and experienced no new episodes of urticaria, exanthema, or any other cutaneous reactions. He denied any past history of urticarial episodes or adverse reactions to the ingestion of food or medication. He had taken acenocoumarol for several weeks, some years earlier, and tolerated it well.

One month after the episode, skin prick tests and intradermal tests with a series of iodinated contrast agents were performed and they were all negative, including the readings at 48 and 96 hours, with the exception of the histamine control. Patch tests with a standard TRUE-TEST series (SmartPractice Denmark ApS) and acenocoumarol (1\% and $5 \%$ ) were also negative. In an attempt to clarify the underlying mechanism, 3 months after the reaction, we performed a lymphocyte transformation test (LTT) with acenocoumarol. Briefly, proliferation of lymphocytes from the allergic patient was measured as previously described [7]. Fresh peripheral blood mononuclear cells separated over a density gradient (Histopaque-1077, Sigma-Aldrich) were incubated for 6 days at 106 cells $/ \mathrm{mL}$ in triplicate with acenocoumarol $(100 \mu \mathrm{g} / \mathrm{mL}-1 \mu \mathrm{g} / \mathrm{mL})$. Phytohemagglutinin $(5 \mu \mathrm{g} / \mathrm{mL})$ was used as a positive control. Proliferation was determined by the addition of $\left[{ }^{3} \mathrm{H}\right]$ thymidine $(0.5 \mu \mathrm{Ci} /$ well $)$ for the final 18 hours of the incubation period. Proliferative responses were calculated as stimulation indices (SI), defined as the ratio between the mean values of counts per minute in cultures with antigen and those obtained without antigen. A positive response, defined as an SI of over 2, was obtained with the drug (Figure). Since the patient had several serious conditions, an oral challenge test with acenocoumarol was not performed and apixaban was tested as an alternative, with good tolerance.

We have reported on a patient who developed a delayed micropapular itchy rash after the intake of acenocoumarol, but progressed favorably when the drug was withdrawn. The implication of acenocoumarol in the reaction was confirmed by a positive LTT. The LTT has been previously used to assess delayed allergic reactions [8]. It offers advantages over patch and intradermal tests, including absolute safety and the assessment of a T-cell response to the drug, especially when it is performed 3 to 9 months after the onset of the reaction.

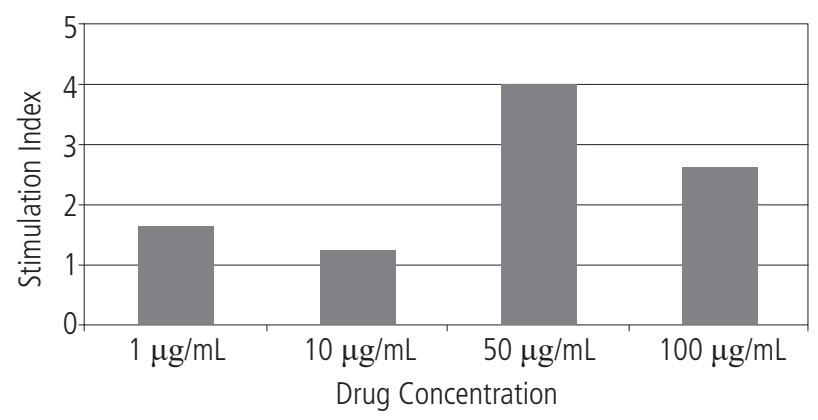

Figure. Lymphocyte transformation test results for acenocoumarol. Results are expressed as the mean of triplicate incubations. The test is considered positive when the stimulation index (SI) is greater than 2 . SI for positive control (phytohemagglutinin) $=44.7$.
To the best of our knowledge, this is the first reported case of hypersensitivity to acenocoumarol in which the implication of this drug has been documented by a positive LTT. The LTT could become a good diagnostic alternative for patients who experience delayed reactions to acenocoumarol or who have disorders that contraindicate an oral challenge test.

\section{Funding}

The authors declare that no funding was received for the present study.

\section{Conflicts of Interest}

The authors declare that they have no conflicts of interest.

\section{References}

1. Storelli F, Daalli Y, Desmeules J, Reny JL. Fontana P. Pharmacogenomics of oral antithrombotic drugs. Curr Pharm. 2016;22(13):1933-49.

2. Valdivielso $M$, Longo I, Lecona $M$, Lázaro P. Cutaneous necrosis induced by acenocoumarol. J Eur Acad Dermatol Veneorol. 2004;18:211-5

3. Alvárez-Pérez A, Gutiérrez-González E, Sánchez-Aguilar D, Toribio J. Atypical calciphylaxis secondary to treatment with acenocoumarol. Actas Dermosifiliogr. 2012;103:79-81.

4. Borrás-Blasco J, Girona E, Navarro-Ruiz A, Matarredona J, Giménez ME, Enríquez R, Martínez A. Acenocoumarol-induced Henoch-Schönlein purpura. Ann Pharmacother. 2004;38: 261-4.

5. Del Río Vizoso M, Femenías Sureda M, Guiu Martí S, Sánchez García J. Leukocytoclastic vasculitis and acenocoumarol. Med Clin (Barc). 2008;130:399.

6. Piñero-Saavedra M, Castaño MP, Camarero MO, Milla SL. DRESS syndrome induced by acenocoumarol with tolerance to warfarin and dabigatran: a case report. Blood Coagul Fibrinolysis. 2013;24:576-8.

7. Pichler WJ, Tilch J. The lymphocyte transformation tests in the diagnosis of drug hypersensitivity. Allergy. 2004;59:809-20

8. Jurado-Palomo J, Cabañas R, Prior N, Bobolea ID, FiandorRomán AM, López-Serrano MC, Quirce S, Bellón T. Use of the lymphocyte transformation test in the diagnosis of DRESS syndrome induced by ceftriaxone and piperacillintazobactam: two case reports. J Investig Allergol Clin Immunol. 2010;20:433-6.

\section{Manuscript received February 28, 2016; accepted for publication,} April 13, 2016.

\author{
Javier Domínguez-Ortega \\ Servicio de Alergología. \\ Hospital Universitario La Paz \\ Paseo de la Castellana, 261 \\ 28046 Madrid, Spain \\ E-mail: javier.dominguez@idipaz.es
}




\section{Kinetics of in Vitro Response to $\beta$-Lactoglobulin in Children Allergic to and Tolerant of Cow's Milk Protein}

Chini $\mathrm{L}^{1}$, Pacciani $\mathrm{V}^{1,2^{*}}$, Corrente $\mathrm{S}^{1,3^{*}}$, Monteferrario $\mathrm{E}^{1,2}$, Romiti $\mathrm{ML}^{1}$, Moschese $\mathrm{V}^{1}$, Angelini $\mathrm{F}^{1,4}$

${ }^{1}$ Division of Pediatrics, Allergy and Immunology Unit, University Hospital of Tor Vergata, University of Rome Tor Vergata, Rome, Italy

${ }^{2}$ Department of Pediatrics, University of Rome Tor Vergata, Children's Hospital Bambino Gesù, Rome, Italy

${ }^{3}$ Division of Pediatrics, S. Paolo Hospital, Civitavecchia, Italy

${ }^{4}$ Immunology, Allergy and Rheumatology Unit, Department of Pediatrics, Centre Hospitalier Universitaire Vaudois (CHUV), Lausanne, Switzerland

*These authors contributed equally to this work.

J Investig Allergol Clin Immunol 2016; Vol. 26(4): 275-277 doi: $10.18176 /$ jiaci.0074

Key words: Cow's milk allergy. Children. Tolerance acquisition.

Palabras clave: Alergia leche de vaca. Niños. Adquisición de tolerancia.

Cow's milk protein allergy (CMPA) affects $2 \%$ to $6 \%$ children according to the EuroPrevall study, and $\beta$-lactoglobulin (BLG) is considered to be the most potent CM allergen. Only $12 \%$ to $37 \%$ of children outgrow CMPA before reaching school age [1], and the mechanism of tolerance remains unclear.

We performed a comparison of T-cell responses in 2 children (P1 and P2) with different CMPA outcomes.

P1, a 13-year-old girl, developed bronchospasm and atopic dermatitis after the introduction of formula milk at 4 months of age. Skin prick tests (SPTs) and specific IgE were positive for CMP. A CMP-free diet was started and resulted in clinical improvement. Oral provocation tests with CMP caused cutaneous itching, urticaria, bronchospasm, and abdominal pain. At the age of 11 years, the SPTs were still positive for $\alpha$-lactalbumin. Oral provocation tests with Parmesan cheese and then fresh milk were successful. The girl currently consumes CMP without any clinical manifestations.

$\mathrm{P} 2$, an 8-year-old girl, developed urticaria, angioedema, and bronchospasm at 4 months of age, after drinking CM. SPTs and specific IgE were positive for CMP. She did not experience further symptoms on a CMP-free diet until an open food challenge with fresh milk caused anaphylaxis. One year later, milk-specific IgE levels were still positive and particularly elevated for casein $(23.23 \mathrm{IU} / \mathrm{mL})$. Several accidental ingestions of Parmesan cheese and food containing CMP resulted in anaphylactic reactions. The girl is still on a CMP-free diet.

In both patients, we analyzed BLG-specific proliferative responses and cytokine production by peripheral blood mononuclear cells (PBMCs) at the time of clinical reactivity to CMP (T1) and during follow up. For P1, T2 and T3 refer to partial and complete tolerance acquisition, respectively, while for $\mathrm{P} 2, \mathrm{~T} 2$ corresponds to an anaphylactic reaction during the $\mathrm{CMP}$ challenge and $\mathrm{T} 3$ corresponds to a few days after the accidental ingestion of CM.

PBMCs were stimulated with an extract of BLG $(10 \mu \mathrm{g} / \mathrm{mL}$, Sigma Aldrich), previously tested for endotoxin content using the LAL test (Cambrex Bio Science), which showed a result of less than $10 \mathrm{EU} / \mathrm{mL}$. In parallel, PBMCs were stimulated with 22 peptides spanning the whole sequence of BLG (20 amino acids for each peptide, with overlapping of 10 amino acids). The cells were cultured in the presence of pools of 4 or 5 peptides (10 $\mu \mathrm{M}$ each, SARM Allergeni).

After 7 days of culture, PBMC proliferation was assessed by overnight $\left[{ }^{3} \mathrm{H}\right]$ thymidine incorporation $(1 \mu \mathrm{Ci} /$ well, Amersham International).

In order to define the extent of the specific proliferative response of allergic patients, we compared the proliferation of the patients' PBMCs to that of 13 healthy age-matched children. A stimulation index (SI) equal to or greater than the mean SI+2SD obtained by stimulating PBMCs from the healthy controls was considered positive. The cutoff was set at $\mathrm{SI}=2.4(\mathrm{BLG})$ and $\mathrm{SI}=1.5$ (pool of BLG peptides).

IL-4, IL-5, IL-9, IL-10, IL-13, IL-17, IFN- $\gamma$, and TNF- $\alpha$ were measured in PBMC culture supernatants using the Bioplex Protein Array System (BioRad) according to the manufacturer's instructions.

In P1, BLG-specific proliferative response revealed a gradual reduction of PBMC proliferation that mirrored the gradual acquisition of clinical tolerance, while in $\mathrm{P} 2$, it revealed a persistent elevation at each time point (Figure A).

In a previous pilot study of 12 patients with a positive proliferative response to $\mathrm{CMP}$, we analyzed $\mathrm{PBMC}$ proliferation to 22 peptides of BLG [2]. Six patients responded to both BLG (SI $>5)$ and BLG peptides. Notably, they responded to peptide pool 9-12, which corresponds to the amino acid sequence 101-140 (DALNENKVLVLDALNENKVLVFCMENSAEPEQSLAC QCLVR) of BLG (Swiss-Prot:P02754). In our patients, the proliferative response to the 9-12 peptide pool showed the same trend as with BLG (Figure B).

In both patients, we investigated type 1 helper $\mathrm{T}$ cell $\left(T_{H} 1\right), T_{H} 2, T_{H} 17$, proinflammatory and regulatory cytokine production upon BLG stimulation. Interestingly, and consistent with the clinical history and outcome, at baseline we observed that IL-5, IL-9, IL-13, and IL-17 cytokines were higher in P2 than P1 (Figure C and D).

During follow up, in P1, IL-5 and IL-4 were undetectable and IL-10, TNF- $\alpha$, IFN- $\gamma$, and IL-17 decreased (Figure C). In P2, by contrast, IL-10 levels did not change, while IFN- $\gamma$ and TNF- $\gamma$ levels increased markedly. IL-4 was undetectable at all times, whereas IL-5, IL-9, IL-13, and IL-17 decreased over time (Figure D).

Our results, while limited to 2 patients, reveal a close relationship between clinical outcome of CMPA and PBMC response to CMP over several years of follow up. Previous work suggests that an IgE-mediated clinical reaction to milk ingestion might be associated with prompt in vivo T-cell proliferation to BLG [3]. Indeed, both of our patients responded to both BLG and BLG peptides. In contrast to P2, P1 showed a progressive reduction in T-cell proliferation to BLG 

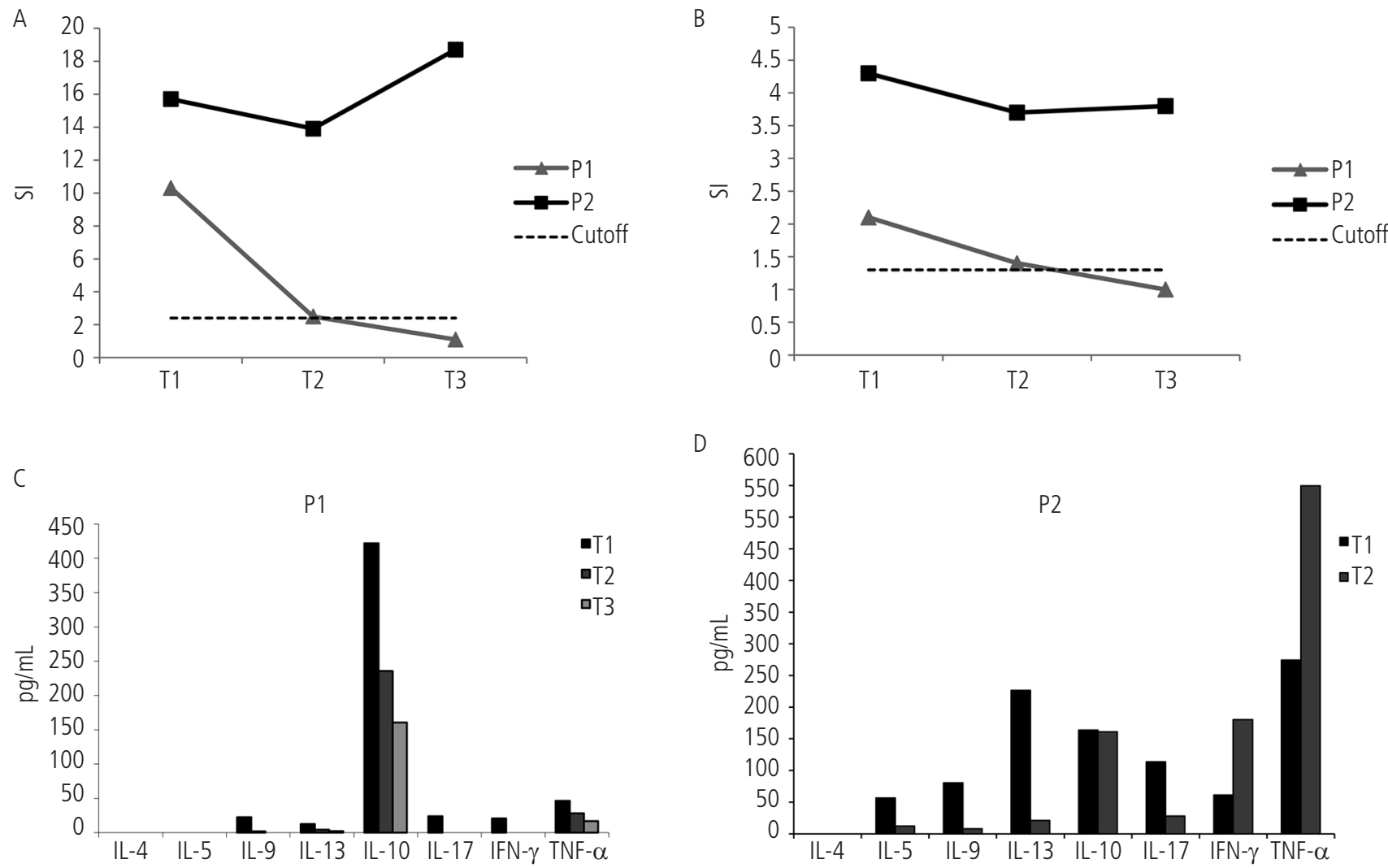

Figure. A, Specific proliferative responses to $\beta$-lactoglobulin in patients $\mathrm{P} 1$ and $\mathrm{P} 2$ at 3 different time points (T1, T2, and T3). B, Specific proliferative responses to $\beta$-lactoglobulin peptides $9-12$ in patients $\mathrm{P} 1$ and $\mathrm{P} 2$ at 3 different time points $(\mathrm{T} 1, \mathrm{~T} 2$, and $\mathrm{T} 3)$. Results are expressed as stimulation index (SI). The dotted line indicates the cutoff response. C and D, IL-5, IL-9, IL-13, IL-10, IFN- $\gamma$, TNF- $\alpha$, and IL-17 production by peripheral blood mononuclear cells in P1 and P2. The level of each cytokine was determined at different time points (T1, T2, and T3 for P1 and T1 and T2 for P2) in culture supernatant using the Bioplex Protein Array System.

and BLG peptides (9-12), in parallel with gradual immune tolerance acquisition.

Importantly, we were able to localize the putative immunogenic region of BLG, which contains a sequence that has been found to be immunodominant in Japanese children affected by CMPA [4]. The identification of T-cell epitopes of BLG and their correlation with a particular HLA in different populations might contribute to the design of peptide-based immunotherapy for CMPA.

With respect to cytokine profile, as expected, we found a higher level of $\mathrm{T}_{\mathrm{H}} 2$ cytokines in $\mathrm{P} 2$ compared to $\mathrm{P} 1$. The absence of substantial amounts of IL- 4 might be due to its consumption during the long culture period used for this experiment.

The high IL-10 levels seen in P1 at T1 might suggest an imminent induction of tolerance, which would be followed by a gradual decline in levels and a reduction in symptoms, in parallel with tolerance acquisition. This is consistent with a recent report and with the notion that IL-10- and IL-10producing T cells are induced early during tolerance induction, as reported for allergen immunotherapy [5,6]. In P2, by contrast, who did not outgrow CMPA, IL-10 levels did not change. The trend for IFN- $\gamma$ levels in the patients is inconsistent with a reported high frequency of INF- $\gamma$-producing T cells in children who have outgrown CMPA [7]. The gradual decrease of TNF- $\alpha$ in P1 and its sharp increase in P2 confirm that TNF- $\alpha$ is involved in the pathogenesis of allergic inflammation. The role of $\mathrm{T}_{\mathrm{H}} 17$ in food allergy remains unclear $[8,9]$. In our previous pilot study of children allergic to CMP, stimulation of PBMCs with BLG induced considerable levels of IL-17 [10]. In the current study, we observed that higher IL-17 levels at diagnosis were correlated with persistence of clinical reactivity later on in both P1 and P2.

In conclusion, we found that BLG-specific proliferation and cytokine production differ between CMPA and CMP tolerance. Moreover, non- $\mathrm{T}_{\mathrm{H}} 2$ cytokines, such as TNF- $\alpha$ and IL-17, might play a role in the clinical manifestation of the disease.

\section{Acknowledgments}

We wish to thank François Spertini for his critical reading of the manuscript.

\section{Funding}

The study was partially funded by the Bambino Gesu' Children's Hospital of Rome, Italy. 


\section{Conflicts of Interest}

The authors declare that they have no conflicts of interest.

\section{References}

1. Skripak JM, Matsui EC, Mudd K, Wood RA. The natural history of IgE-mediated cow's milk allergy. J Allergy Clin Immunol. 2007;120:1172-77

2. Pacciani $V$, Silenzi $R$, Corrente $S$, Monteferrario $E$, Roma D, Moretti R, Moschese V, Rossi P, Chini L, Angelini F. Characterisation of $T$ cell epitopes of beta-lactoglobulin in cow's milk allergic patients. Allergy. 2011;66 (S 94):S120-S123

3. Vocca I, Canani RB, Camarca A, Ruotolo S, Nocerino R, Radano G, Del Mastro A, Troncone R, Gianfrani C. Peripheral blood immune response elicited by beta-lactoglobulin in childhood cow's milk allergy. Pediatr Res. 2011;70:549-554.

4. Inoue $R$, Matsushita S, Kaneko H, Shinoda S, Sakaguchi $H$, Nishimura $Y$, Kondo N. Identification of beta-lactoglobulinderived peptides and class II HLA molecules recognized by $T$ cells from patients with milk allergy. Clin Exp Allergy. 2001;31:1126-34.5.

5. Fishbein $A B$, Qamar $N$, Erickson KA, Kwasny MJ, Cai $M$, Szychlinski C, Singh AM, Fuleihan RL . Cytokine responses to egg protein in previously allergic children who developed tolerance naturally. Ann Allergy Asthma Immunol. 2014;113: 667-70.

6. Urra JM, Carrasco P, Feo-Brito F, De La Roca F, Guerra F, Cabrera CM. Immunotherapy reduces CD40L expression and modifies cytokine production in the CD4 cells of pollen allergy patients. J Investig Allergol Clin Immunol. 2014:24:98-105.

7. Tsuge I, Kondo $Y$, Tokuda $R$, Kakami $M$, Kawamura $M$, Nakajima Y, Komatsubara R, Yamada K, Urisu A. Allergen- specific helper T cell response in patients with cow's milk allergy: Simultaneous analysis of proliferation and cytokine production by carboxyfluorescein succinimidyl ester dilution assay. Clin Exp Allergy. 2006;36:1538-45.

8. Herberth $G$, Daegelmann $C$, Röder $S$, Behrendt $H$, Krämer $U$, Borte M, Heinrich J, Herbarth O, Lehmann I. IL-17E but not IL17A is associated with allergic sensitization: results from the LISA study. Pediatr Allergy Immunol. 2010;21:1086-90.

9. Dhuban KB, d'Hennezel E, Ben-Shoshan M, McCusker C, Clarke A, Fiset P, Mazer B, Piccirillo CA. Altered T helper 17 responses in children with food allergy. Int Arch Allergy Immunol. 2013;162:318

10. Pacciani V, Silenzi R, Corrente S, Moschese V, Chini L, Angelini F. Induction of Th17 after allergen stimulation in children affected by Cow's milk allergy. XIV Meeting of European Society of Immunodeficiencies (ESID), Istanbul-Turkey. 2010; (P299):150.

Manuscript received December 30, 2015; accepted for publication, May 6, 2016

Loredana Chini and Stefania Corrente Divisione di Pediatria, Unità di Allergologia e Immunologia Pediatrica Policlinico di Tor Vergata Università di Roma Tor Vergata Viale Oxford 81

00133 Roma, Italy

E-mail: chini@med.uniroma2.it, stefania.corrente@yahoo.it 